\title{
WOMEN'S RESISTANCE TOWARDS OPPRESSION IN ETAF RUM'S A WOMAN IS NO MAN
}

\author{
Frisky Nur Salvianny ${ }^{1, *}$, Eka Nurcahyani ${ }^{2}$ \\ ${ }^{1}$ English Department, Faculty of Languages and Arts, Universitas Negeri Jakarta, Jakarta 13220, Indonesia \\ ${ }^{2}$ English Department, Faculty of Languages and Arts, Universitas Negeri Jakarta, Jakarta 13220, Indonesia
}

\section{A RTICLE INFO}

Keywords:

Arab-American

Feminism

Oppression

Resistance

Article History:

Received: 01/10/2020

Accepted: 20/11/2020

Available Online:

$30 / 11 / 2020$

\section{A B S T R A C T}

Women have been oppressed through the domination of patriarchy that controls their lives. Therefore, women resist the oppression by speaking up for their rights to own one's life. This study investigates women's oppression and their resistance in the novel A Woman Is No Man by Etaf Rum. Deploying Patricia Hill Collins' theory of Matrix of Domination and Self-Definition, this study applied a descriptive-analytical method in analyzing how women experience oppression and their actions in resisting it. Portrayed by the three generations of Arab-American female characters, the result of this study finds women are experiencing oppressions managed within the four domains of power: structural, disciplinary, hegemonic, and interpersonal domain of power. While men have the privilege of being free, women are burden with the family's reputation and domestic duties that turn them into a docile individual. Furthermore, women's self-definition helps them to gather their self-worth to counter the oppression. Women's resistances are realized through their ability to maintain self-valuation and respect, self-reliance and independence, and personal empowerment through the act of being brave in voicing their thoughts, going to college, and living on their own, and encouraging each other to raise awareness of self-definition.

2442-305X / (C) 2020 The Author, this is open access article under the (CC-BY-NC) license (https://creativecommons.org/licenses/by-nc/4.0/), DOI: 10.19105/ojbs.v14i2.3847

\footnotetext{
* Corresponding Author:

Email address: friskysalvianny@gmail.com (F. N. Salvianny)
}

\section{A. Introduction}

Oppression is a social act of a dominant group that controls the others and limits the suppressed group that being devalued, exploited, and deprived of privileges. ${ }^{1}$ Women's oppression occurs

\footnotetext{
${ }^{1}$ Abdulrahman Abdulwaheed Idris et al., "Depiction of Women as the Primary Architects of Their Own
}

within the gendered unfairness treatment between women and men that is further managed by patriarchy to justify that men are more respected than women.

Oppression: A Masculinist Critique of El Saadawi's Woman at Point Zero," International Journal of Applied Linguistics and English Literature 7, no. 4 (2018):

$206-12$, https://doi.org/10.7575/aiac.ijalel.v.7n.4p.206. 
Historically, women's lives were believed to be linked with their biological destiny in bearing children. It was convinced that women's exclusion from public activities was based on their unsuited hormones for activities that required intellectual, authority, physical strength, and speed. ${ }^{2}$ Therefore, women are likely to be dependent on men as they do not own economic and social freedom.

Women's dependency on men has made them become part of men's property that their voices remain silent. The powerlessness of women in owning life has given men full authority to treat women as objects and possessions in which violence against women becomes a common feature of society. Based on recent data from the World Health Organization in 2017, as much as $35 \%$ of women worldwide had experienced physical and/or sexual violence in their lifetime. $^{3}$

This kind of violence exists throughout the world, including Palestine. Statistics data of Palestinian Central Bureau of Statistics show that Palestinian women are commonly experienced domestic violence caused by their husbands with a percentage of $37 \%$, with $65,3 \%$ preferred to keep silent regarding the violence they experienced. ${ }^{4}$ These

2 Davita Glasberg and Deric Shannon, 2 Political Sociology: Oppression, Resistance, and the State (California: SAGE Publication Ltd., 2010), 7.

3 World Health Organization, "Violence against Women," accessed November 29, 2019, https://www.who.int/news-room/factsheets/detail/violence-against-women.

${ }^{4}$ Palestinian Central Bureau of Statistics, "Violence Survey in the Palestinian Society" (Household Violence, 2011), http://www.pcbs.gov.ps/pcbs- data show that women's oppression starts at home, where domestic abuse is commonly experienced.

Women in Palestinian society are oppressed through the limitation of economic freedom and cultural practices. Women are prohibited from accessing public activities outside their community and are discouraged from developing economic independence. Hence, it is inevitable that women tend to be dependent on stability and security from men. ${ }^{5}$ As Palestinian society adopted a high-context culture that is highly affected by family, community, and institutions within their surroundings, Palestinian women are facing oppression both from the family and their area, including in their migrated area. Arab immigrants live closely in one neighborhood and rely upon each other to seek social needs, economic support, and cultural and religious maintenance. ${ }^{6}$

In the U.S, Palestinian immigrants tend to preserve their cultural practices that force women to fulfill their gender expectations. Arab-American women are burden with the family's reputation that their actions and attitudes should be lined

\footnotetext{
metadata-en-v4.3/index.php/catalog/407/studydescription.

${ }^{5}$ Tal Meler, "Money, Power, and Inequality within Marriage among Palestinian Families in Israel," The Sociological Review 68, no. 3 (2020): 623-40, https://doi.org/10.1177/0038026119881093.

6 Ben K. Beitin and Mireille Aprahamian, "Family Values and Traditions," in Biopsychosocial Perspectives on Arab Americans, ed. Sylvia C. Nassar-McMillan, Kristine J. Ajrouch, and Julie Hakim-Larson (Boston, MA: Springer US, 2014), 67-88, https://doi.org/10.1007/978-1-4614-82383_4.
} 
with Arab's culture as the family's image remains essential within the society.

As women are suppressed, a resistance towards oppression is developed to fight for their rights. The critical point of women's resistance towards patriarchy is to counter men's domination in taking the power of women's lives. Besides, resistance is not merely opposed to challenging domination, but also it enhances women's sense of empowerment to seek freedom. ${ }^{7}$

Women's resistance in the U.S. is categorized into three different waves that indicate each's wave goals of resistance as a representation of the flow of the feminist movement. ${ }^{8}$ These waves were firstly begun in the early nineteenth century and the movement continues in the present time. Furthermore, women's resistance towards the system of patriarchy is realized by maintaining their self-definition. In alignment with this, Collins noted that women's constructed knowledge of self is an essential power in conquering oppression as it is the basic resistance of women's struggle to challenge oppression. ${ }^{9}$

The issue of Arab-American women's oppression and their resistance towards the patriarchal system are

\footnotetext{
7 Alex Demirović, "More than Resistance. Striving for Universalization: Subjects, Representations, Contexts," in Resistance: Subjects, Representation, Context, ed. Martin Butler, Paul Mecheril, and Lea Brenningmeyer (Bielefield: Transcript Verlag, 2017), https://doi.org/10.14361/9783839431498-003.

8 Rory Dicker, A History of U.S. Feminisms (California: Seal Press, 2008), 5.

${ }^{9}$ Patricia Hill Collins, Black Feminist Thought (New York: Routledge, 2000), 99.
}

reflected in the 2019 domestic fiction novel entitled $A$ Woman is No Man by Etaf Rum. This novel told a story of three generations of Arab-American women who are oppressed through the cultural hegemony of a male-dominated society that justifies women's subordination. ${ }^{10}$ In the novel, women are expelled from public spaces, including school, as women are taught their lives should be revolved around marriage, family, and childbearing. They are encouraged to follow the hegemonic commonsense of women's roles, which limits them to choose their life path and own their voices. The traditional Arabic household practices are maintained to keep women under men's authority that restricts them to find their liberation.

The author of the novel, Etaf Rum is an Arab-American immigrant that wrote this novel to speak on behalf of herself and women in her community that have the same experience of being oppressed. As a debut novel, this novel has successfully become a worth-to-read novel that has been listed as Goodreads Choice Award Nominee for Best Fiction and Debut Novel of 2019, one of Cosmopolitan's Best Books by POC for 2019, a Washington Post 10 books to read in March 2019, an Electric Lit 20 Best Debuts of the First Half of 2019, a The Millions Most Anticipated Books of 2019, and a New York Times best-selling novel.

\footnotetext{
${ }^{10}$ Etaf Rum, A Woman is No Man (New York: HarperCollins Publisher, 2019).
} 
Furthermore, the issue of oppression and resistance in the novel can be analyzed by deploying Patricia Hill Collins' theory of Matrix of Domination and Self-Definition. Collins suggests that women's oppression is managed through intersecting oppressions of race, class, gender, sexuality, ethnicity, nation, and religion. These oppressions are interrelated and organized through the structural, disciplinary, hegemonic, and interpersonal domain of power. As the four domains of power are intersected with one another to keep women being docile and under men's domination, struggles in resisting oppression are needed to overcome the oppression.

Women's awareness on their power and opposing matrix of domination is realized through a term called SelfDefinition. It refers to women's power in resisting the controlling images and discriminatory practices that oppress women through new construction of selfknowledge. Acknowledging self-worth is an essential point of women's resistance as it points out their self-valuation and respect, self-reliance and independence, and personal empowerment.

Some studies discussed similar issues of women's oppression and their resistance. By deploying Spivak's theory of Subaltern, Mohammad Shafiqul Islam, and Rama Islam in 2019 examine Indian women's self-exploration and encouragement to fight against the patriarchal system of Indian society. ${ }^{11}$ The

11 Mohammad Shafiqul Islam and Rama Islam, "Representation of Postcolonial Indian Women: Bimla and Nanda Kaul in Anita Desai's Clear Light two leading characters of the novel represent Indian women's experiences in coping with oppression. Meanwhile, using the same approach of Spivak's Subaltern, Imran et al. in 2020 explore the voice of subaltern women through the works of Afghanistani female writers. $^{12}$ Women's writings are written as a tool to speak on behalf of oppressed women that they need to be recognized, respected, and have equal rights to be free. In another study, Roni Strier and Ilham Zidan discussed arranged marriage practices in Israel. ${ }^{13}$ By deploying Crenshaw's theory of Intersectionality, arranged marriage is not merely seen as an oppressive cultural practice but also women's goal of life and a path of freedom.

In discussing the novel, two previous related studies analyze similar issues. The first study conducted by Sari that examines patriarchal oppression to the main characters in Etaf Rum's $A$ Woman is No Man. ${ }^{14}$ By deploying Sylvia Walby's Patriarchy Theory, it is found that the main characters of the novel are experiencing patriarchal oppressions

of Day and Fire on the Mountain," South Asian Review 40, no. 1-2 (2019): 51-64, https://doi.org/10.1080/02759527.2019.1593754.

12 Muhammad Imran et al., "Veiled Courage: Inside the Women's Resistance against Violence through Their Writings," Asian Journal of Women's Studies 26, no. 1 (2020): 74-93, https://doi.org/10.1080/12259276.2020.1718392.

13 Roni Strier and Ilham Zidan, "Arranged Marriages: An Oppressed Emancipation?," Women's Studies International Forum 40 (2013): 203-11, https://doi.org/10.1016/j.wsif.2013.07.005.

${ }^{14}$ Alfatih Nur Indah Sari, "Patriarchal Oppression to the Main Characters in Etaf Rum's A Woman Is No Man" (Undergraduate Thesis, Univesitas Negeri Maulana Malik Ibrahim Malang, 2020), 1. http://etheses.uin-malang.ac.id/21820/. 
through the patriarchal mode of production, male violence, patriarchal state, and patriarchal culture. In alignment with this, Wulandari et. al. studied the representation of liberal feminism in the novel by deploying Stuart Hall's Representation Theory and Betty Freiddan's Feminine Mystique. ${ }^{15}$ This study highlights women's movement to fight for equal rights to men and achieve their goals by speaking out their rights.

Differing from all the previous studies, this study does not merely discuss women's oppression, but also their struggles to cope with patriarchy. Therefore, Collins' theory of Matrix of Domination is used to analyze women's oppression in a patriarchal society that highlights oppression within four domains of power: structural, disciplinary, hegemonic, and interpersonal. Meanwhile, the theory of women's Self-Definition is used to analyze women's power in defining themselves and realizing selfworth as an act of resistance. This theory points out that women's resistance is realized through new construction of selfconsciousness, which resulted in acknowledging their self-valuation and respect, self-reliance and independence, and personal empowerment.

Based on the explanation concerning patriarchal practices that oppress women, this study sheds to investigate women's oppression and their

15 Mega Dwi Wulandari, Supiastutik Supiastutik, and Hat Pujiati, "The Representation of Liberal Feminism in A Woman Is No Man by Etaf Rum," Lentera: Jurnal IImiah Kependidikan 12, no. 2 (2019): 237-48, https://doi.org/10.12345/lentera.v12i2.421. resistances portrayed in the novel $A$ Woman is No Man by Etaf Rum.

\section{B. Method}

This study used a descriptiveanalytical method in examining women's oppression and their resistance. The descriptive-analytical method involves identifying and exploring particular phenomena to describe, explain, and interpret data in creating a critical evaluation concerning the issue. ${ }^{16}$

The narrations and dialogues in the novel $A$ Woman is No Man by Etaf Rum were taken as the data source of this study to represent women's oppression and struggle to overcome domination. To support the analysis, this study deployed Collins's theory of Matrix of Domination and Self-Definition in identifying the collected data from the novel that indicate women's resistance towards oppression. The collective data were then classified and taken based on the characteristics of the issue to further being analyzed and interpreted with regard to the given theory.

\section{Results}

In this part, two topics were discussed. First, female characters' oppression through examining the matrix of domination includes four domains of power: structural, disciplinary, hegemonic, and interpersonal domain of power. Second, the oppressions that are experienced by the characters are resisted through their struggle of liberating

${ }^{16}$ C. R. Kothari, Research Methodology: Method and Techniques (New Delhi: New Age International Ltd Publisher, 2004), 3. 
themselves. Women's resistance is seen by the realization of self-definition that comes by maintaining self-valuation and respect, self-reliance and independence, and personal empowerment.

\section{Women's Oppression in Etaf Rum's A Woman is No Man}

A Woman is No Man tells a story of three generations of Arab-American women who faced oppression through the limitation of voicing their thoughts. Being the first generation in the family, Fareeda is forced to keep their culture of origin alive. Hence, she organizes arranged marriage for all of her children and treats her daughter differently than the son. She forces Sarah, her daughter, to follow the rules she made, including the standard of beauty, women's domestic roles, and arranged marriage.

Besides Sarah, Isra, who is married to Adam, Fareeda's first son, experiences a similar oppression treatment. Isra's intention in marrying Adam was to get her freedom by moving to the U.S. However, she does not feel any different treatment of being in Palestine or the U.S. Women are still being controlled and managed to fulfill their basic duties of marriage, domestic roles, and bearing children.

Deya, as Fareeda's granddaughter, is not an exception. She is forced to get to know Nasser as her suitor for the marriage that is arranged by Fareeda. Although Deya does not want to marry at an early age as she has dreams to fulfill, Fareeda strongly opposes this idea since it could bring a negative judgement to the family.
The oppressions experienced by the female characters are managed through the practices of a matrix of domination. Matrix of domination refers to the intersecting oppressions of gender, race, sexuality, and nation. ${ }^{17}$ The first domain that manages women's oppression is the structural domain of power, which covers social institutions to manage women's subordination. The family works as a social institution that controls women's life path, including their choice of marriage. In an Arab community, marriage is part of women's life goals seen as a tool to keep the family's dignity. ${ }^{18}$ Therefore, all women in the novel are forced to agree on arranged marriage to prevent negative judgment from the community.

“You've seen other girls who've disobeyed their parents, refusing to get married, or worse, getting divorced, and look at them now! Living at home with their parents, their heads hanging in shame! Is that what you want?" 19

As arranged marriage is a practice that is inherited throughout generations, Fareeda, who forced her daughter and granddaughter, used to experience a similar attempt. Fareeda was fourteen when she got married to Khaled without ever met him before. The practice of marriage that occurs to underage women violates human rights as it happens

\footnotetext{
${ }^{17}$ Collins, Black Feminist Thought, 18.

18 Salam Aboulhassan and Krista M. Brumley, "Carrying the Burden of a Culture: Bargaining With Patriarchy and the Gendered Reputation of Arab American Women," Journal of Family Issues 40, no. 5 (2019): 637-61, https://doi.org/10.1177/0192513X18821403.

19 Rum, A Woman Is No Man, 38.
} 
without the bride's consent or is too young to make such a life's choice. ${ }^{20}$

Fareeda's granddaughter-Deya, who dreams of going to college, disagrees on early marriage and always wants to continue her education instead. However, Fareeda finds the idea of going to college is out of the question as education is not meant for women. The exclusion of women in pursuing education is managed to keep women's inferiority. ${ }^{21}$

Also, women tend to be dependent on men regarding stability and security as they do not have the knowledge of the world outside their domestic spheres. ${ }^{22}$ In a conversation between Deya and Nasser, he does not forbid Deya from going to college, but he does not agree either for Deya to get a job as she will be fully provided. These exclusions of women from social institutions such as school and office are organized through the structural domain of power, which keeps women under men's authority.

The second domain of the matrix of domination is the disciplinary domain of power managed through bureaucratic hierarchies to create "quiet, orderly, docile, and disciplined women". ${ }^{23}$ Rules and policies are made to maintain

20 Dorit Segal-Engelchin, Efrat Huss, and Najlaa Massry, "The Experience of Early Marriage: Perspectives of Engaged and Married Muslim Women in Israel," Journal of Adolescent Research 31, no. 6 (2016): 725-49, https://doi.org/10.1177/0743558415605167.

${ }^{21}$ Collins, Black Feminist Thought, 277.

22 Meler, "Money, Power, and Inequality within Marriage among Palestinian Families in Israel," 625.

${ }^{23}$ Collins, Black Feminist Thought, 281. women's consciousness in abiding the oppressive system. In the novel, women are suppressed with the competition among them to fulfill the standard of beauty to be chosen as a bride. Since women are controlled by the normative femininity of beauty, speech, and mannerisms, it dictates women to fulfill their gender expectations. ${ }^{24}$ Therefore, women strive to meet their normative femininity through appearance to obtain self-worth and others' approval. ${ }^{25}$ Fareeda used to forbid Sarah to use her front teeth to crack watermelon seed as it might ruin her perfect smile. She also does not mind to compare Sarah to the other women in the community to judge their appearances. "Have you seen Hannah's dark skin and course hair? And the girl is barely five feet tall. You're much prettier." ${ }^{26}$ The comparison of women's beauty to be chosen as a bride is a justification of beauty standards to keep women under surveillance.

Besides being oppressed as a daughter, women are also oppressed through the discrimination of gender in their marriage lives. Women as a wife are

\footnotetext{
24 Salam Aboulhassan and Krista M. Brumley, "Carrying the Burden of a Culture: Bargaining with Patriarchy and the Gendered Reputation of Arab American Women," Journal of Family Issues 40, no. 5 (2019): 637-61, https://doi.org/10.1177/0192513X18821403.

25 Mary Inman, Anna Snyder, and Kelvin Peprah, "Religious Body Affirmations Protect Body Esteem for Women Who Base Self-Worth on Appearance or Others' Approval," Mental Health, Religion \& Culture 19, no. 1 (2016): 98-111, https://doi.org/10.1080/13674676.2015.1124634.

${ }^{26}$ Rum, A Woman Is No Man, 162.
} 
pushed to serve, please, and follow the husbands and be obedient to the husband's rules. Therefore, any actions against the husband's orders may lead to domestic violence that victimizes women. ${ }^{27}$

"She could picture Adam now, his eyes bulging, his jaw clenching and unclenching. She could feel his fingers around her arms, squeezing tight. Feel him shoving her against the wall, pulling her hair, slapping her across the face. Feel his fingers around her throat, her skin starting to numb, could see the room going white. No. She couldn't face him." 28

Isra, who used to get beaten by Adam could easily imagine her punishment every time she does something against Adam's will. The inferiority feeling of being punished is evidence of oppression within the disciplinary domain of power that manages women to be docile and under surveillance.

The third domain is the hegemonic domain of power that deals with power domination on ideology, culture, and consciousness which covers the justification of oppression within the other domains of power. $^{29}$ Ideology works as the basic idea of common interests among a community created through the society's system of structure which makes it seem natural, normal, and inevitable. One of the

\footnotetext{
27 Amarat Zaatut and Muhammad M Haj-Yahia, "Beliefs about Wife Beating among Palestinian Women from Israel: The Effect of Their Endorsement of Patriarchal Ideology," Feminism \& Psychology 26, no. 4 (2016): 405-25, https://doi.org/10.1177/0959353516647071.

${ }^{28}$ Rum, A Woman Is No Man, 227.

${ }^{29}$ Collins, Black Feminist Thought, 284.
}

common ideologies that produces gender discrimination is the acceptance of a baby's gender. In Arab society, a baby boy is always expected rather than a baby girl in a baby birth as a boy would carry family's lineage while a girl would be a family's burden. ${ }^{30}$ The son preference is a well-known practice within the West Bank camp, Palestine that justifies the importance of patrilineality and patriarchal kinship, which is inherited by the son. ${ }^{31}$ When Isra gets pregnant, Fareeda always expects the baby's gender is a boy. Isra's incapability to give birth to a boy has forced her to get pregnant as soon as possible so that the family would have someone to carry their name.

"Easy for you to say. Do you know how hard it is to raise a girl in this country? Do you? Soon you'll be pulling your hair out! You need a son to help you. To carry on our name."32

The discrimination of gender does not merely happen during the early age of a baby, but it continues until they grow up. As a grown-up, women are burdened with the family's reputation that controls their behaviors and manners to prevent being the subject of gossip in the community. ${ }^{33}$

\footnotetext{
${ }^{30}$ Alean Al-Krenawi and Stephen O. Jackson, "Arab American Marriage: Culture, Tradition, Religion, and the Social Worker," Journal of Human Behavior in the Social Environment 24, no. 2 (2014): 115-37, https://doi.org/10.1080/10911359.2014.848679.

31 Cheryl A. Rubenberg, Palestinian Women: Patriarchy and Resistance in the West Bank (Boulder, Colorado: Lynne Rienner Publishers, 2001), 38.

${ }^{32}$ Rum, A Woman Is No Man, 99.

33 Bilal Tawfiq Hamamra, "The Misogynist Representation of Women in Palestinian Oral Tradition: A Socio-Political Study," Journal of Gender Studies 29, no. 2 (2020): 214-26, https://doi.org/10.1080/09589236.2019.1604328.
} 
Being the family's reputation holder, women are forced to agree on arranged marriage as prevention from negative judgments that commonly stick to unmarried women. When a woman rejects getting married, she will be considered an immodest daughter, which brings shame to the family. ${ }^{34}$ Therefore, women tend to agree on arranged marriage as it becomes part of their ideology of being women of the community.

"Eventually, she'd have to agree to someone. She could only refuse for so long unless she wanted to ruin her reputation and her sisters' reputations as well. She could hear their neighbors in her head. That girl is bad. She isn't respectable. Something must be wrong with her." 35

Through the hegemonic commonsense, women believe that the highest value of womanhood is marriage and motherhood. As a result, women who could not fulfill the value of womanhood would shame the family. In alignment with this idea, the concept of honor is strongly stuck to women's images, affecting their mental health. Although women's oppression might bring a problem to their mental health, seeking professional help is not a common action and will be considered a crazy person who has spiritual illness. ${ }^{36}$ Isra, who could not cope with the constant demand of having a boy

\footnotetext{
34 Anthony Marcus et al., "Between Choice and Obligation: An Exploratory Assessment of Forced Marriage Problems and Policies among Migrants in the United States," Social Policy and Society 18, no. 1 (2019): 19-36, https://doi.org/10.1017/S1474746417000422.

${ }^{35}$ Rum, A Woman Is No Man, 38.

36 Al-Krenawi and Jackson, "Arab American Marriage," 128.
}

while being pressured with domestic duties and child bearing, faces a problem with her mental health. Furthermore, the women's exclusion from earning knowledge at school has resulted in their lack of awareness regarding mental health and bringing the idea of myth instead.

Besides the ideology commonsense of myth, the hegemonic domain of power also preserves women's oppression through the idea of women's fate. To maintain the community's cultural practices, women are taught that they are meant to fulfill their gender expectations while ignoring their own voice, and this idea is inherited through generations. Therefore, it has risen women's inferiority feeling that imprisons women from liberation.

"Life here isn't so different from life back home, with all the cooking, cleaning, folding, and ironing. And the women here-they live no better. They still scrub floors and raise children and wait on men to order them around. A part of me hoped that women would be liberated in this country. But you were right, Mama. A woman will always be a woman." ${ }^{37}$

Women's oppression through the ideology of culture is one reason why it seems familiar for women to recognize and limit their places in the community. Thus, the idea of gender, marriage, and myth has created commonsense that prevent women from challenging the domination that suppresses them.

The fourth domain covers interpersonal relationships among community members that occur through

${ }^{37}$ Rum, A Woman Is No Man, 146. 
an individual's failure to recognize day-today practices that justify the other women's subordination. In the novel, a mother is placed in the highest hierarchy among the other female family members. Therefore, she should be respected and valued that the other family's members have to serve the mother's needs. "With four teenage girls in the house, she should have been giving orders like a queen". ${ }^{38}$ The hierarchy among women brings impact on women's oppression as the action of serving one's need justifies suppression.

As oppression within the interpersonal domain of power works on daily practices, the oppression is uncommonly easy to be recognized. ${ }^{39}$ In a conversation between Fareeda and her friend, news comes to the community that Umm Ahmed's daughter is getting divorced. Hearing the news, Fareeda directly thinks that the bride causes divorce without looking closely at the actual problem. Furthermore, women's accusation is seen as an acceptable expression, although it is practically an oppressive action.

Interpersonal oppression does not merely happen within micro-level context among women's relationships with each other, but also from outside the community. In the U.S, Arab-American people are stuck with the judgment of being terrorists or extremists. Ever since the event of $9 / 11$, Arab-Americans commonly experience multiple oppression

\footnotetext{
${ }^{38}$ Rum, A Woman Is No Man, 223.

${ }^{39}$ Collins, Black Feminist Thought, 285.
}

by negative stereotyping, open prejudice, hate crimes, civil rights violations, deportation, and incarceration. ${ }^{40}$ In the novel, Deya is wearing a hijab in a public space, and she can feel everyone's eyes on her, looking at her with a suspicious stare. "After a few deep breaths, Deya took a furtive look around the train car. Everywhere she turned, people were staring." ${ }^{41}$ This kind of discriminative action justifies the everyday oppressive action through the negative judgment and alienation of women's fashion. Thus, other responses to giving a judgment to a woman have proved women's oppression within the interpersonal domain of power.

Women's oppression, portrayed by female characters in the novel, is managed through the intersecting oppression among those four domains of power. Therefore, women's action is needed to challenge those oppressions and liberate themselves from oppressive practices.

\section{Women's Resistance in Etaf Rum's A Woman is No Man}

Women's resistance is an essential point of the struggle to oppose domination that had oppressed women and turned them into submissive individuals. Therefore, the awareness of women's individual power to resist oppression is an important aspect of resistance. A brandnew consciousness of self is realized by

\footnotetext{
${ }^{40}$ Sally A. Kakoti, "Arab American Women, Mental Health, and Feminism," Journal of Women and Social Work 27, no. 1 (2012): 60-70, https://doi.org/10.1177/0886109912437572.

${ }^{41}$ Rum, A Woman Is No Man, 97.
} 
acknowledging women's self-definition that brings their awareness of self-value and self-worth. Furthermore, maintaining self-definition is realized through women's ability to be aware of their self-valuation and respect, self-reliance and independence, and personal empowerment that are beneficial for women to find the courage in opposing domination.

The first aspect of helping women in realizing their self-worth is through women's self-valuation and respect. This aspect is the key factor of women's selfdefinition as self-valuation has risen women's self-esteem. In the novel, Sarah is discriminated through her gender that does not allow her to have the same rights as men. Consequently, gender discrimination has weakened her selfesteem, making her think she is treated differently from her brothers and her American friends. To gain her selfesteem, she tries to find her value of being a worthy individual through her selfworth's evaluation. Then, she finds the strength to overcome gender discrimination through her ability to recognize her worth as a woman.

Women's awareness of self-value has also occurred through the media of literature. Literature provides various stories of women's life experiences and their strategies in opposing oppressive domination. By reading women's writings, women are inspired to gather the selfpower that leads them to their liberation. ${ }^{42}$

42 Heidi Fritz Horzella, "Imagined Sisterhoods: The Impact of Reading about Significant Women on the Construction of Feminist Subjectivities on British
Isra used to think that a way to be loved is by being obedient to her husband. However, literature has changed her perspective that love comes from her self. Self-love is needed to get the sense of being worthy that brings impact on her self-esteem.

"For so many years, she had believed that if a woman was good enough, obedient enough, she might be worthy of a man's love. But now, reading her books, she was beginning to find a different kind of love. A love that came from inside her, one she felt when she was all alone, reading by the window. And through this love, she was beginning to believe, for the first time in her life, that maybe she was worthy after all." ${ }^{43}$

Besides recognizing self-valuation, women's ability to respect and be respected by others works to boost selfworth valuation. As society has disregarded their existence, women maintain their relationship by supporting each other for having self-respect and respect for others. Therefore, the sisterhood bound among women unites their forces to survive in the oppressive domination. ${ }^{44}$ As Sarah has already recognized her self-definition power, she tries to convince Deya to find her own self-value. Through Sarah's advice, Deya is convinced that self-respect leads her to

\footnotetext{
Women Schoolteachers," Women's Studies International Forum 79 (2020): 102331, https://doi.org/10.1016/j.wsif.2019.102331.

43 Rum, A Woman Is No Man, 181.

${ }^{44}$ Cassandra Fetters, "The Continual Search for Sisterhood: Narcissism, Projection, and Intersubjective Disruptions in Toni Morrison's Sula and Feminist Communities," Meridians: Feminism, Race, Transnationalism 13, no. 2 (2016): 28-55, https://doi.org/10.2979/meridians.13.2.03.
} 
a realization of her self-worth which makes her rethink her life path while changing to her fate.

Women's self-valuation and respect is the core concept of women's selfdefinition as it addresses the actual content to the awareness of self-love. Through this concept, women are able to boost their self-esteem and learn to love and appreciate themselves. Thus, women's self-love and sisterhood bound among women is essential in rising new consciousness of self-worth.

The second aspect of gathering women's self-definition is through selfreliance and independence. The strength to oppose oppression is not merely taken from women's power of self-valuation, but also the power to be independent and rely on themselves. Sarah, who is aware of her value as an individual, finds the courage to resist oppression by voicing her will in declining arranged marriage. She challenges women's normative femininity image for being docile by being brave in speaking up her mind, although it means being beaten. Her power in defining self-reliance has taken her to independence, which brings her the power to handle everything on herself. Therefore, she runs away from home to reject arranged marriage and lives on her own ever since then.

"Sarah spoke slowly, a half-smile on her lips. "I haven't been in Palestine this entire time, or at all. I never got married." 45
Sarah's spirit of self-reliance and independence leads her to get in touch with Deya and encourages her to speak up. Women's strength in resisting oppression is gathered through sisterhood bound as the way women talk to one another, and the relationship among women is vital to their growth and wellbeing. ${ }^{46}$ Through Sarah's experience of resistance, she is fully independent regarding her choice of life, and she does not let others control her. In addition, she reaches out to Deya to change her vision on marriage and womanhood, which shows the spirit of independence as she can encourage other women's liberation.

Women's power in maintaining selfreliance and independence brings a new consciousness of a free mind necessary for their sphere of freedom. In resisting oppression, women gather the strength to find their self-worth and be dependent on themselves. Therefore, women's power of independence enables them to empower others for their liberation as their strength in maintaining self-definition has justified their capability to oppose domination.

The third aspect of women's selfdefinition is women's personal empowerment. Personal empowerment is an essential aspect of self-definition as the power in resisting oppression lies within each individual's power. As women's lives have been controlled, a change in opposing domination could be realized through personal space in

${ }^{46}$ Collins, Black Feminist Thought, 104.

${ }^{45}$ Rum, A Woman Is No Man, 128.

OKARA: Jurnal Bahasa dan Sastra, Vol. 14, No. 2, November 2020 
changing the consciousness of freedom. Rising women's consciousness of freedom is vital in bringing a new life vision, leading them to recognize awareness, sisterhood, and vision of womanhood for both women as individuals and groups. $^{47} \mathrm{~A}$ new consciousness of self-worth could help women to empower themselves to make a change in their lives. As the first character who finds the power in recognizing her self-worth, Sarah encourages herself to make a change by acting according to her will. The power to step out of the oppressive domination that controls her life has brought her to the state of being independent. Therefore, she maintains her personal empowerment by living on her own and creating a new life.

"But I managed. I stayed with a friend for the first year until I could afford to live on my own. Then I rented a small apartment in Staten Island. I worked two jobs to pay for community college and changed my last name so no one could find me." ${ }^{48}$

As Sarah's personal empowerment has helped her to find her freedom, a similar attempt is followed by Isra. She runs away from home to save herself and her children from oppressive domination that could be taken their lives away. Living under oppression since she was in Palestine, Isra does not want her

\footnotetext{
${ }^{47}$ Kelli Zaytoun and Judith Ezekiel, "Sisterhood in Movement: Feminist Solidarity in France and the United States," Frontiers: A Journal of Women Studies 37, no 1 (2016): 195 , https://doi.org/10.5250/fronjwomestud.37.1.0195.

${ }^{48}$ Rum, A Woman Is No Man, 128.
}

daughters to experience the same things as they used to. The realization of personal empowerment has taken Isra to be brave to step up out of fate in being a docile woman. She tries to take her daughters to save them from domination that taken rights in having choices to live. When Isra takes her daughters to a train station, the open door of the train shows a metaphorical meaning of freedom.

"When it stopped in front of them and its metal doors opened wide, a pulse of victory swooned through her chest. They would finally be free." 49

Besides Sarah and Isra, Deya also finds her personal empowerment to make a change in her life. By learning the stories of her parents and Sarah's experience, she decides to oppose Fareeda's idea of getting married after high school and continuing her study instead. Deya's resistance is seen through her courage in speaking up her mind. She dares to apply for college in Manhattan and refuses Nasser's proposal.

In the end, Sarah, Isra, and Deya find their own liberation through their individual action. As women's resistances take a different kind of forms, the results of their act of freedom are varied. Sarah runs away from home and lives happily on her own, Isra finds the courage to free herself, and Deya enters university and is brave in refusing arranged marriage.

${ }^{49}$ Rum, A Woman Is No Man, 274. 


\section{Conclusion}

Etaf Rum's A Woman is No Man portrays women's oppression and their resistance to opposing domination. By deploying Patricia Hill's Collins theory of Matrix of Domination, found that women are oppressed through the four intersecting domains of power: structural, disciplinary, hegemonic, and interpersonal domain of power. In challenging oppression, women try to maintain their power of self-definition to be free from domination. Women's ability to acknowledge their self-worth is a core factor in opposing oppression as women's path of freedom lies within individuals' power. Women's self-definition helped them to maintain their self-valuation and respect, self-reliance and independence, and personal empowerment are considered as key factors to act of the resistance.

\section{References}

Abdulwaheed Idris, Abdulrahman, Rosli Talif, Arbaayah Ali Termizi, and Hardev Kaur Jujar. "Depiction of Women as the Primary Architects of Their Own Oppression: A Masculinist Critique of El Saadawi's Woman at Point Zero." International Journal of Applied Linguistics and English Literature 7, no. 4 (2018): 206-12.

https://doi.org/10.7575/aiac.ijalel.v.7 n.4p.206.

Aboulhassan, Salam, and Krista $M$. Brumley. "Carrying the Burden of a Culture: Bargaining with Patriarchy and the Gendered Reputation of Arab American Women." Journal of Family Issues 40, no. 5 (2019): 63761.

https://doi.org/10.1177/0192513X18 821403.
Al-Krenawi, Alean, and Stephen O. Jackson. "Arab American Marriage: Culture, Tradition, Religion, and the Social Worker." Journal of Human Behavior in the Social Environment 24, no. 2 (2014): 115-37. https://doi.org/10.1080/10911359.20 14.848679 .

Beitin, Ben K., and Mireille Aprahamian. "Family Values and Traditions." In Biopsychosocial Perspectives on Arab Americans, edited by Sylvia C. Nassar-McMillan, Kristine J. Ajrouch, and Julie Hakim-Larson, 67-88. Boston, MA: Springer US, 2014. https://doi.org/10.1007/978-14614-8238-3_4.

Collins, Patricia Hill. Black Feminist Thought. New York: Routledge, 2000.

Demirović, Alex. "More than Resistance. Striving for Universalization: Subjects, Representations, Contexts." In Resistance: Subjects, Representation, Context, edited by Martin Butler, Paul Mecheril, and Lea Brenningmeyer, 32-44. Bielefield: Transcript Verlag, 2017. https://doi.org/10.14361/978383943 1498-003.

Dicker, Rory. A History of U.S. Feminisms. California: Seal Press, 2008.

Fetters, Cassandra. "The Continual Search for Sisterhood: Narcissism, Projection, and Intersubjective Disruptions in Toni Morrison's Sula and Feminist Communities." Meridians: Feminism, Race, Transnationalism 13, no. 2 (2016): 28-55.

https://doi.org/10.2979/meridians.13 .2.03.

Fritz Horzella, Heidi. "Imagined Sisterhoods: The Impact of Reading about Significant Women on the Construction of Feminist Subjectivities on British Women Schoolteachers." Women's Studies International Forum 79 (2020): 102331. 
https://doi.org/10.1016/j.wsif.2019.1 02331.

Glasberg, Davita, and Deric Shannon. 2 Political Sociology: Oppression, Resistance, and the State. California: SAGE Publication Ltd., 2010.

Hamamra, Bilal Tawfiq. "The Misogynist Representation of Women in Palestinian Oral Tradition: A SocioPolitical Study." Journal of Gender Studies 29, no. 2 (2020): 214-26. https://doi.org/10.1080/09589236.20 19.1604328.

Imran, Muhammad, Yuee Chen, Xiaofei Matthew Wei, and Samina Akhtar. "Veiled Courage: Inside the Women's Resistance against Violence through Their Writings." Asian Journal of Women's Studies 26, no. 1 (2020): 74-93. https://doi.org/10.1080/12259276.20 20.1718392.

Inman, Mary, Anna Snyder, and Kelvin Peprah. "Religious Body Affirmations Protect Body Esteem for Women Who Base Self-Worth on Appearance or Others' Approval." Mental Health, Religion \& Culture 19, no. 1 (2016): 98-111. https://doi.org/10.1080/13674676.20 15.1124634.

Islam, Mohammad Shafiqul, and Rama Islam. "Representation of Postcolonial Indian Women: Bimla and Nanda Kaul in Anita Desai's Clear Light of Day and Fire on the Mountain." South Asian Review 40, no. 1-2 (2019): 51-64. https://doi.org/10.1080/02759527.20 19.1593754.

Kakoti, Sally A. "Arab American Women, Mental Health, and Feminism." Journal of Women and Social Work 27, no. 1 (2012): 60-70. https://doi.org/10.1177/0886109912 437572.
Kothari, C. R. Research Methodology: Method and Techniques. New Delhi: New Age International Ltd Publisher, 2004.

Marcus, Anthony, Popy Begum, Laila Alsabahi, and Ric Curtis. "Between Choice and Obligation: An Exploratory Assessment of Forced Marriage Problems and Policies among Migrants in the United States." Social Policy and Society 18, no. 1 (2019): 19-36. https://doi.org/10.1017/S147474641 7000422.

Meler, Tal. "Money, Power, and Inequality within Marriage among Palestinian Families in Israel." The Sociological Review 68, no. 3 (2020): 623-40. https://doi.org/10.1177/0038026119 881093.

Palestinian Central Bureau of Statistics. "Violence Survey in the Palestinian Society." Household Violence, 2011. http://www.pcbs.gov.ps/pcbsmetadata-env4.3/index.php/catalog/407/studydescription.

Rubenberg, Cheryl A. Palestinian Women: Patriarchy and Resistence in the West Bank. Boulder, Colorado: Lynne Rienner Publishers, 2001.

Rum, Etaf. A Woman Is No Man. New York: HarperCollins Publisher, 2019.

Sari, Alfatih Nur Indah. "Patriarchal Oppression to the Main Characters in Etaf Rum's A Woman Is No Man." Undergraduate Thesis, Univesitas Negeri Maulana Malik Ibrahim Malang, 2020. http://etheses.uinmalang.ac.id/21820/.

Segal-Engelchin, Dorit, Efrat Huss, and Najlaa Massry. "The Experience of Early Marriage: Perspectives of Engaged and Married Muslim Women in Israel." Journal of Adolescent Research 31, no. 6 (2016): 725-49. https://doi.org/10.1177/0743558415 605167. 
Strier, Roni, and Ilham Zidan. "Arranged Marriages: An Oppressed Emancipation?" Women's Studies International Forum 40 (2013): 20311. https://doi.org/10.1016/j.wsif.2013.0 7.005 .

World Health Organization. "Violence Against Women." Accessed November 29, 2019. https://www.who.int/news-room/factsheets/detail/violence-againstwomen.

Wulandari, Mega Dwi, Supiastutik Supiastutik, and Hat Pujiati. "The Representation of Liberal Feminism in A Woman Is No Man by Etaf Rum." Lentera: Jurnal IImiah Kependidikan 12, no. 2 (2019): 23748.

https://doi.org/10.12345/lentera.v12i 2.421 .

Zaatut, Amarat, and Muhammad M HajYahia. "Beliefs about Wife Beating among Palestinian Women from Israel: The Effect of Their Endorsement of Patriarchal Ideology." Feminism \& Psychology 26, no. 4 (2016): 405-25. https://doi.org/10.1177/0959353516 647071.

Zaytoun, Kelli, and Judith Ezekiel. "Sisterhood in Movement: Feminist Solidarity in France and the United States." Frontiers: A Journal of Women Studies 37, no. 1 (2016): 195.

https://doi.org/10.5250/fronjwomestu d.37.1.0195. 